\title{
ANALISIS FILOSUFIS PEMIKIRAN IBNU MISKAWAIH (SKETSA BIOGRAFI, KONSEP PEMIKIRAN PENDIDIKAN, DAN RELEVANSINYA DIERA MODERN)
}

\author{
Ahmad Wahyu Hidayat \\ State Islamic University Sunan Kalijaga Yogyakarta \\ Email: ahmadwahyuhidavat95@gmail.com \\ Ulfa Kesuma \\ State Islamic University Raden Fatah Palembang \\ Email: kesumaulfa@gmail.com
}

\begin{abstract}
This study aims to determine the philosophical analysis of Ibn Miskawaih thoughts (biographical sketches, concepts of educational thought, and their relevance in the modern era). Education is an effort made by someone to make a change towards a better one. In Indonesia education is more interpreted as a formal institution that has the aim to develop the academic potential of students in order to realize educational goals. One of the leaders of Islamic education, Ibn Miskawaih. Ibn Miskawaih is one of the leaders of Islamic education who contributed ideas to education. The focus of this study on the philosophical analysis of Ibn Miskawaib's thoughts (biographical sketches, concepts of educational thought, and their relevance to modern diera). This study uses the method of literature and analytical studies to build a theoretical framework in this article. In conclusion, Ibn Maskawaih considered the significance of education and the environment for humans in relation to moral formation. Thus human beings with their minds can choose and distinguish which ones should be done and which ones should be left behind. Ibn Maskawaib's thinking in education cannot be separated from his concept of man and morals. Ibn Maskawaih views human beings as having three powers, from those three types of power which are two from the material element and one from the spirit of God.
\end{abstract}

\section{Key words: Moral Education Thought and Ibn Miskawaih}

\begin{abstract}
Abstrak
Penelitian ini bertujuan untuk mengetahui analisis filosofis pemikiran ibnu miskawaih (sketsa biografi, konsep pemikiran pendidikan, dan relevansinya di era modern). Pendidikan adalah usaha yang dilakukan oleh seseorang agar terjadi perubahan kearah yang lebih baik. Di Indonesia pendidikan lebih diartikan sebagai sebuah lembaga formal
\end{abstract}

Nazhruna: Jurnal Pendidikan Islam

Vol. 2 No 1 2019. Issn: 2614-8013. Hal. 87-107

DOI: $10.3153 /$ nzh.v2i1.189 
yang memiliki tujuan untuk mengembangkan potensi akademik peserta didik dalam rangka mewujudkan tujuan pendidikan. Salah satu tokoh pendidikan islam yaitu Ibnu Miskawaih. Ibnu Miskawaih adalah salah satu tokoh pendidikan Islam yang memberikan sumbangsih pemikiran terhadap pendidikan. Fokus penelitian ini pada analisis filosufis pemikiran ibnu miskawaih (sketsa biografi, konsep pemikiran pendidikan, dan relevansinya diera modern). Penelitian ini menggunakan metode kepustakaan dan studi analisis untuk membangun kerangka teori pada artikel ini. Kesimpulanya Ibnu Maskawaih melihat begitu pentingnya arti pendidikan dan lingkungan bagi manusia untuk mempermudah proses pembinaan akhlak. Dengan demikian manusia dengan akalnya dapat memilih dan membedakan apa yang seharusnya dilakukan dan apa yang harus ditinggalkan. Pemikiran Ibnu Maskawaih dalam pendidikan bertumpu pada konsep tentang manusia dan pendidikan akhlak. Ibnu Maskawaih memandang manusia sebagai makhluk yang memiliki tiga daya, dari tiga macam daya tersebut yaitu terdiri dua terdapat pada unsur materi dan yang satu lagi terdapat pada ruh Tuhan.

\section{Kata kunci: Pendidikan Etika dan Pemikiran Ibnu Miskawaih}

\section{PENDAHULUAN}

Pendidikan bertujuan untuk membentuk pribadi yang berkualitas, baik jasmani maupun rohani, secara konseptual pendidkan mempunyai peran strategi dalam membentuk anak didik menjadi manusia berkualitas, tidak saja berkualitas dalam aspek skill, kognitif, afektif tetapi juga aspek spiritual. Hal ini membuktikan pendidikan mempunyai andil besar dalam mengarahkan anak didik mengembangkan diri berdasarkan pontensi dan bakatnya melalui pendidikan anak memungkinkan menjadi pribadi shaleh, pribadi berkualitas secara skill, kognitif, dan spiritual. ${ }^{1}$

Pada kenyataannya, pendidikan belum mampu mencapai tujuan yang diinginkan prilaku-prilaku tidak terpuji masih banyak terjadi di masyarakat, dari mulai merebaknya penggunaan narkoba, asusilah, pelanggaran HAM, pembunuhan, penganiayaan, minimnya kejujuran, dan lain sebagainya.

Etika atau ahklak menjadi sesuatu yang sangat penting bagi kelangsungan hidup berbangsa. Dan bernegara. Dengan etika watak bangsa

${ }^{1}$ Istighfarotul Rohmaniyah. Pendidikan Etika: Konsep Jiwa dan Etika Perspektif Ibnu Miskawaih dalam Kontribusinya di Bidang Pendidikan. (Malang: UIN Malang Press, 2010), hlm.109 . 
yang berkarakter dan memiliki jati diri akan terbentuk, pada endingnya negara tersebut akan dihargai dan diperhitungkan oleh bangsa manapun di dunia ini.

Islam memberikan perhatian yang sangat besar terhadap etika atau akhlak. Hal ini dapat dilihat secara historis maupun teologis dalam ajaran islam itu sendiri. Begitu banyak intelektual muslim yang telah membahas akhlak secara filosofi, diantaranya adalah Abu Bakar Ar-Razi, Ibnu Miskawaih, Al Ghazali, dan lain sebagainya. ${ }^{2}$

Filosofi Islam terbesar yang memberikan perhatian khusus mengenai fisafat etika adalah Ibnu Miskawaihi, walaupun para ahli fisafatnya itu merupakan sintesis dari berbagai pandangan, terutama dari fisafat etika yunani (Plato, Aristoteles, dan Gulen) dan unsur-unsur etika Islam. ${ }^{3}$ Walaupun demikian, usahanya sangat berhasil dalam melakukan harmonisasi antara pemikiran filsafat dan pemikiran islam, terutama dalam bidang akhalak samapai beliau dijuluki sebagai Bapak etika islam. Ia juga dijuluki sebagai guru ketiga (al-Mu'alim al-Tsalits) setelah Al Farabi yang dijuluki Guru kedua (alMualimal al- Tsani), dan Aristoteles sebagai Guru pertama (al-Mu'allim al Awal). ${ }^{4}$

Dari hal tersebut penulis meneliti lebih lanjut tentang analisis filosufis pemikiran ibnu miskawaih sketsa biografi, konsep pemikiran pendidikan, dan relevansinya diera modern saat ini.

\section{Biografi Ibnu Maskawaih}

Nama lengkap Ibnu Miskawaih adalah Abu Ali Ahmad ibnu Muhammad ibnu Ya'kub ibnu Miskawaih. Ia dilahirkan di kota Rayy, yang puing-puingnya terletak di dekat Teheran Modern. Iran pada tahun 320 H/932 M dan wafat di Asfahan pada tanggal 9 Shafar 421 H/16 Februari $1030 \mathrm{M}^{5}$

Sejarah hidup ibnu miskawaih tidak banyak diketahui oleh banyak orang. Namun para penulis di dalam berbagai literatur atau referensi tidak menjelaskan biografinya secara terrinci. Namun demikian ada beberapa hal

${ }^{2}$ Ar-Razi lahir di Kota Ray, dekat Teheran, Iran pada 1 Sya'ban 251 H/ 865 M Ibnu Miskawaih juga berasal dari kota Ray, lahir pada 330 H/ 941 M. Sedangkan Al Ghazali lahir di Grazal, Thus, Khurusan, Iran pada 450 H/ 1058 M Lihat Sirajuddin Zat, Filsafat Islam: Filsafat dan Filsafatnya, (Jakarta: Raja Grafindo Persada, 2007),

${ }^{3}$ Istighfarotul Rahmaniyah, Pendidikan Etika: Konsep Jiwa dan Etika Perspektif Ibnu Miskawaih dalam Kontribusinya di Bidang Pendidikan..., hlm 110.

${ }^{4}$ Mustofa, Filsafat Islam, (Bandung: Pustaka Setia, 2007), hlm 168.

${ }^{5}$ Ahmad Syar'i, Filsafat Pendidikan Islam (Jakarta: Pustaka Firdaus, 2005), hlm 91 
yang perlu dijelaskan bahwa Ibnu Miskawaih belajar sejarah terutama Tarikh al-Thabari kepada seorang guru yang bernama Abu bakar ibnu Kamil AlQadhi dan belajar filsafat kepada Ibnu Al-Khammar seorang musafir yang banyak memunyai karya-karya Ariestoteles.

Ibnu Maskawah belajar sejarah terutama Tarikh al-Thabari kepada seorang guru yang bernama Abu Bakar Ahmad Ibnu Kamil al-Qadhi (350 H/960 M). Beliau juga mendalami ilmu kimia bersama Abu al-Thayyib alRazi. Iqbal mengungkapkan bahwa Ibnu Maskawaih adalah seorang pemikir teistis, moralis dan sejarahwan Persia paling tersohor dan terhebat di zamannya. $^{6}$

Ibnu Maskawaih hidup di zaman Dinasti Buwaihi. Kemudian beliau meninggalkan Ray menuju ke Baghdad dan mengabdi pada Pangeran Buwaihi. Ketika beliau kembali ke Ray, ia dipercaya menjaga perpustakaan besar yang menyimpan banyak rahasia, sehingga beliau digelar dengan al-Khazin.

Ada di antara penulis yang mengatakan bahwa Ibnu Miskawaih sebelum masuk Islam beragama Majusi. Kredibilitas statemen ini perlu diragukan, karena dilihat dari namanya, Muhammad, menunjukkan nama orang muslim. Agaknya benar yang dikemukakan Aburrahman Badawi bahwa statemen ini lebih tepat pada ayahnya ketimbang kepadanya.

Ibnu Miskawaih seorang penganut Syiah. Indikasi ini didasarkan pada pengabdiannya kepada sultan dan wasir-wasir Syiah dalam masa pemerintahan Bani Buwaihi (320-448 H). Ketika Sultan Ahmad 'Adhud AlDaulah memegang tampuk pemerintahan, ia menduduki jabatan yang penting, seperti diangkat menjadi Khazim, penjaga perpustakaan yang besar dan bendahara negara.

Disiplin ilmunya meliputi kedokteran, bahasa, sejarah dan filsafat. Akan tetapi, ia lebih populer sebagai seorang filolosof akhlak (al-fasafat al'amaliyat) ketimbang filosof ketuhanan (al-fasafat al-nazhariyat al-Ilabiyah). Agaknya ini dimotivasi oleh situasi masyarakat yang sangat kacau di masanya, seperti minuman keras, perzinaan dan lain-lain. ${ }^{8}$

\footnotetext{
${ }^{6}$ M.M. Syarif, Para Filosof Muslim (Cet. XI; Bandung: Mizan, 1998), hlm. 83-84

${ }^{7}$ Hasyimiyah Nasution, Filsafat Islam (Cet. I; Jakarta: Gajah Mada Press, 1999), hlm. 57.

${ }^{8}$ Sirajuddin Zar, Filsafat Islam : Filosof dan Filsafatnya, Jakarta: PT RajaGrafindo Persada, 2012). hlm. 127-128
} 


\section{Karya-Karya Ibnu Maskawaih}

Miskawaih tidak hanya dikenal sebagai seorang pemikir, tetapi juga sebagai penulis yang produktif. Ia menghasilkan banyak karya tulis, tapi hanya sebagai kecil yang sekarang masih ada. Jumlah buku dan artikel yang berhasil oleh Ibnu Miskawaih ada 41 buah. Menurut Ahmad Amin, semua karya Ibnu Miskawaih tersebut tidak luput dari kepentingan filsafat etika. Sehubungan dengan hal tersebut, maka tidak mengherankan jika ia dikenal sebagai seorang moralis. Tulisan-tulisan dan karya-karya Ibnu Miskawaih banyak dipengaruhi oleh filsafat Yunani, Plato, Aristoteles, Forforius, Enbadgless, dan Filsuf yunani lainnya serta kaum Neo-Platonis. ${ }^{9}$

Lepas dari semua hal yang berkaitan dengan tulisan Ibnu Miskawaih yang dipengaruhi filsafat yunani, Ibnu Miskawaih merupakan sosok filsuf muslim yang berhasil. Keberhasilan Ibnu Miskawaih ini dibuktikan dengan banyaknya buku yang ditulisnya. Ia telah menulis 41 buah buku dan artikel yang selalu berkaitan dengan filsafat akhlak. Dari 41 karyanya itu, 15 buah sudah dicetak, 8 buah masih berupa manuskrip dan 18 buah dinyatakan hilang..$^{10}$ Dalam buku The History of The Muslim Philosophy ada beberapa karya tulisan ibnu miskawah yaitu:

1. Al-Fauz al-Akbar (Tentang Keberhasilan Besar),

2. Al-Fauz al-Asghar (Tentang Keberhasilan Kecil),

3. Tajarib al-Umam (Tentang Pengalaman Bangsa-bangsa Sejak Awal Sampai ke Masa Hidupnya),

4. Uns al-Farid (Kumpulan Anekdot, Syair, Peribahasa dan Kata-kata Mutiara),

5. Tartib al-Sa'adat (Tentang Akhlak dan Politik),

6. Al-Musthafa (Syair-yair Pilihan),

7. Jawidan Khirad (Kumpulan Ungkapan Bijak),

8. Al-Jami,

9. Al-Siya (Tentang Aturan Hidup),

10. Tahzib al-Akblaq (Pendidikan Akhlak),

11. Risalat fi al-Lazzat wa al-Alam fi Jaubar al-Nafs,

12. Ajwibah wa Al-as'ilah fi An-Nafs wa al-Aql (Tanya Jawab Tentang Jiwa)

9 Rosif. "Dialektika Pendidikan Etika dalam Islam (Analisis Pemikirn Ibnu Miskawaih)." Jurnal Pendidikan Agama Islam, 3, No. 2 (November 2015): 394-417.

10 Istighfarotul Rahmaniyah, Pendidikan Etika: Konsep Jiwa dan Etika Perspektif Ibnu Miskawaih dalam Kontribusinya di Bidang Pendidikan..., hlm 112. 
13. Al-Jawab fi al-Masa'il al-Salas (Jawaban Tentang Tiga Masalah),

14. Risalat fi-Jawab fi-Su'al Ali ibn Mubammad Abu Hayyan al-Shufi fi Haqiqat al-'Aql,

15. Thaharat al-Nafs (Kesucian Jiwa). ${ }^{11}$

\section{Konsep Pemikiran Pendidikan Islam Menurut Ibn Maskawaih}

1. Tujuan

Ibn Miskawaih menjabarkan konsep pendidikan akhlak secara luas dalam karyanya yang berjudul Tahzib al-Akhlâq. Dalam kitab tersebut, ia menegaskan bahwa akhlak adalah suatu keadaan jiwa dan keadaan ini menyebabkan jiwa bertindak tanpa dipikir dan dipertimbangkan terlebih dahulu. Ia membagi asal keadaan jiwa ini menjadi dua jenis, yaitu alamiah dan bertolak dari watak, dan tercipta melalui kebiasaan dan latihan. Menurutnya, akhlak itu alami sifatnya, namun akhlak juga dapat berubah cepat atau lambat melalui disiplin serta nasehat-nasehat yang mulia. Pada mulanya, keadaan ini terjadi karena dipertimbangkan dan dipikirkan, namun kemudian melalui praktik terus menerus akan menjadi akhlak. Dengan demikian, sesuai dengan definisi tersebut, akhlak anak usia dini bertolak dari wataknya dan ia dapat berubah melalui latihan dan pembiasaan. ${ }^{12}$

Berdasarkan karya Ibn Miskawaih, setidaknya ada tiga tujuan pendidikan akhlak. Pertama. Mencetak tingkah laku manusia yang baik, sehingga manusia itu dapat berperilaku terpuji dan sempurna sesuai dengan hakikatnya sebagai manusia. Kedua. Mengangkat manusia dari derajat yang paling tercela, derajat yang dikutuk oleh Allah SWT. Ketiga. Mengarahkan manusia menjadi manusia yang sempurna (al-insân alkâmil). Dalam konteks ini, tujuan pendidikan akhlak anak usia dini adalah menumbuhkan dan membentuk perilaku mulia dalam diri anak agar dapat menjadi manusia sempurna, sehingga anak dapat menjadi manusia mulia di hadapan Allah SWT. ${ }^{13}$

11 Dedi Supriydi, Pengantar Filsafat Islam: Konsep, Filusuf dan Ajarannya, (Bandung: Pustaka Setia, 2009). hlm. 112-113.

12 Tim Pengembang Ilmu Pendidikan, Ilmu dan Aplikasi Pendidikan, Jakarta: Imperial Bhakti Utama, 2007), hlm. 21.

${ }^{13}$ Rosnita. "PEMBENTUKAN AKHLAK ANAK USIA DINI Menurut IBNU MISKAWAIH." MIQOT XXXVII, no. 2 (juli-desember 2013): 396-414. 
Ibnu Miskawih dalam pemikirannya tentang etika, ia memulainya dengan menyelami jiwa manusia. Ia memandang bahwa ilmu jiwa memiliki keutamaan sendiri di- bandingkan dengan ilmu-ilmu yang lain. Manusia tidak mampu untuk meraih suatu ilmu kecuali telah mengetahui ilmu jiwa sebelumnya. Kapan seseorang memahami ilmu jiwa maka hal itu menjadi bantuan baginya untuk memperoleh ilmu yang lain.

Mengetahui tentang keadaan-keadaan jiwa (abwal an Nafs) merupakan pondasi untuk ilmu-ilmu yang lain seperti teologi, etika, logika. Karena mengetahui jiwa, seseorang memiliki senjata untuk melihat yang benar dan batil dalam masalah keyakinan dan antara kebaikan dankeburukan. Oleh karena itu, pemikiran etika miskawaih dibangun atas pandangannya terhadap jiwa. ${ }^{14}$

Dengan demikian jiwa bukanlah tubuh dan bukan juga bagian dari tubuh. Jiwa dapat mengetahui esensi dan substansi sendiri yaitu akal. Ia pun tidak pernah memerlukan sesuatu yang lain untuk mengetahui sesuatu, kecuali dirinya sendiri. Oleh karena itu, akal aqil (orang yang berfikir), ma'qul (obyek yang dipikirkan) merupakan salah satu kesatuan yang saling terkait. ${ }^{15}$

Eksistensi dan sifat jiwa yang dijelaskan oleh Ibnu Maskawaih seperti itu ternyata mempunyai kekuatan yaitu:

a. Kekuatan rasioanal atau daya pikir (qumwah natiqah) yang disebut quwwah Malikiah merupakan fungsi jiwa yang tertinggi, kekuatan berfikir dan melihat fakta yang dipergunakan dari dalam diri adalah otak sebagai alat.

b. Kekuatan apetitif atau maarah (quwwah ghadabiyah) yaitu keberanian menghadapi tantangan, ambisi terhadap kekuasaan, kedudukan dan kehormatan. Kekuatannya disebut juga quwwah subu'iyah (daya kekuasaan). Daya yang dipergunakan dari dalam diri yaitu hati.

c. Kekuatan gairah atau nafsu (qunwah syahwiyab) disebut dengan quwwah babimiah yakni daya binatangi seperti dorongan nafsu makan, keinginan dalam melakukan kelezatan makanan, minuman, seksualitas dan segala macam kenikmatan inderawi (al-ladrizay albissiyah). Alat yang digunakan dari dalam diri yaitu perut.

${ }^{14}$ Ahmad Amin, Dhubr al- Islam, Jus II (Beirut: Dar Al Kitab Al Araby, 1969), hlm. 177.

${ }^{15}$ Rosnita. "PEMBENTUKAN AKHLAK ANAK USIA DINI Menurut IBNU MISKAWAIH." MIQOT XXXVII, no. 2 (juli-desember 2013): 396-414. 
Kekuatan tersebut dapat dialami oleh setiap orang secara berbeda-beda. Kuat lama suatu kekuatan itu tergantung kepada perangai, adat kebiasaan atau pendidikannya. ${ }^{16}$

Yang menarik dari pemikiran Ibnu Maskawaih yaitu kekuatan jiwa yang akan melahirkan kekuatan (fadbilah) sewaktu gerak aktifitasnya normal (mu'tadilah), sesuai dan seimbang. Rinciannya adalah:

a. Bila gerak jiwa rasional (natiqah) normal, tidak menyeleweng dari hakekatnya dan kecenderungannya terhadaap ilmu pengetahuan yang benar, lahir keutamaan ilmu (fadbilah al-Im), kemudian kebijaksanaan (al-Hikmahi).

b. Bila gerak jiwa apetitif (ghadabiyah) serasi dan seimbang, patuh terhadap petunjuk jiwa rasional, tidak bergejolak diluar batas, maka terjadilah keutamaan kesantunan (fadbilah al-Hilm), lalu disusul dengan keberanian (al-Suja'ab).

c. Bila gerak jiwa gairah (bahimyah) serasi dan seimbang, diantara kontrol daya jiwa rasional, patuh kepadanya, tidak mengikuti hawa nafsu, lahirlah keutamaan keberhasilan diri (fadbilah al-Iffab), lalu kedermawanan (al-Saha). Bila ketiga keutamaan tersebut al-Hikmah, al-Iffah dan al-Suja'ah bisa seimbangan dan kerasian anatara satu sama lain, maka munculah keadilan (al-adalah) yang sebenarnya. ${ }^{17}$ Adapun musuh dari keempat sifat utama itu adalah bodoh, penakut, rakus dan dzalim. ${ }^{18}$ Ini merupakan sifat-sifat utama yang pokok dan dibawah masing-masing sifat ini terdapat sejumlah sifat-sifat lain yang berkaitan satu sama yang lain seperti:

1) Sifat hikmah (kebijaksanaan) memiliki sejumlah sifat yang dapat dipersiapan yaitu cerdik, mengingat, berfikir dan sebagainya. Sifat ini berasal dari jiwa yang rasional, jiwa yang berfikir analisis agar dapat mengetahui segala yang ada karena keberadaannya.

2) Sifat iffah (kesucian diri) sifat ini mempunyai sejumalh sifat diantaranya sifat malu, sabar, qana'ah, sopan, zuhud dan lain-lain. Hal ini dapat dilihat pada waktu seseeorang mengendalikan hawa nafsu.

3) Sifat al-Suja'ah (keberanian). Sifat ini meliputi sifat jiwa besar,

${ }^{16}$ Ibnu Maskawaih, Tahzib al-Akblaq wa al-Takbthir al-A'raq (Mesir: al-Husainiyah, 1392), hlm. 13.

${ }^{17}$ Ibid.

${ }^{18}$ Hasyimiyah Nasution, Filsafat Islam..., hlm. 63. 
berani menghadapi bahaya, santun, tabah, tidak lemah mental dan lain-lain. Hal ini berasal dari jiwa apetitif yang terlihat pada diri manusia, ketika jiwa apetitif dikendalikan oleh keutamaan kebijaksanaan dan dipergunakan sesuai akal pikiran untuk menghadapi masalah yang beresiko seperti tidak gentar menghadapi perkara sesulit apapun.

4) Sifat al-Adalah (keadilan). Sifat ini memiliki sifat persaudaraan, kerukunan, menyambung rasa keluarga dan lain-lain. Hal ini berasal dari sifat utama yang terdapat pada jiwa sebagai hasil perpaduan (ijtima') dari ketiga keutamaan. ${ }^{19}$

Sifat-sifat utama hanya ada pada diri manusia, tidak terdapat pada hewan. Manusia tidak mewujudkan sifat-sifat tersebut tanpa bantuan orang lain. Karena itulah manusia merupakan makhluk sosial dan berfikir yang memerlukan adanya masyarakat dan negara di mana dia akan hidup dan saling membantu antara sesama sehingga dapat mencapai tujuan hidup yakni kebahagiaan. Demikian pula sifat keutamaan hanya terdapat pada diri manusia saja. ${ }^{20}$ Kemudian Ibnu Maskawaih menjelaskan tentang bagian dari sifat-sifat keutamaan tersebut. Oleh karenanya jiwa yang sempurna merupakan jiwa manusia yang dapat mencapai kebahagiaan.

Bahagia menurut pendapat Ibnu Maskwaih mempunyai dua tingkat yaitu Pertama, ada manusia yang tertarik dengan hal-hal yang bersifat benar dan mendapat kebahagiannya. Kemudian ia mempunyai rasa rindu dengan kebahagiaan jiwa, kemudian ia berusaha untuk memperolehnya. Kedua, manusia yang memisahkan dirinya dari kenikmatan benda agar memperoleh kebahagiaan lewat jiwa. Kebahagiaan yang bersifat benda tidak dingkarinya, tetapi dipandang sebagai tanda-tanda kekuasaan Allah. Ibnu Maskawaih mengungapkan bahwa kebahagiaan bersifat benda mengandung makna kepedihan dan penyesalan serta menghambat pertumbuhan jiwa untuk menuju kehadirat sang maha agung Allah Swt. Kebahagian jiwa adalah kebahagiaan yang paling sempurna dan mampu

\footnotetext{
${ }^{19}$ Nizar, Pemikiran Etike Ibnu Miskawaih, JURNAL AQLAM, Journal of Islam and Plurality, Volume 1, Nomor 1, Juni 2016, hlm. 35-42.

${ }^{20}$ Nizar, Pemikiran Etika Ibnu Miskawaih, JURNAL AQLAM, Journal of Islam and Plurality, Volume 1, Nomor 1, Juni 2016, hlm. 35-42.
} 
mengantarkan manusia untuk memiliki derajat yang paling tinggi (malaikat). ${ }^{21}$

Keberadaan jiwa menurut Ibnu Maskawaih adalah untuk membantah kaum materialis yang tidak mengakui adanya roh bagi manusia. Roh tidak berbentuk materi sekalipun ia bertempat pada maeri, karena materi hanya menerima satu bentuk dalam waktu tertentu. Dengan demikian, jiwa dan materi adalah dua hal yang berbeda, imateralaitas jiwa itu menunjukkan ketidakmateriannya, karena kematian adalah karakter yang material. ${ }^{22}$

2. Materi

Ibnu Maskawaih mendefenisikan bahwa materi pendidikan harus menekankan pada materi pembelajran yang bermanfaat bagi terciptanya akhlak mulia dan menjadikan pedoman manusia agar sesuai dengan tujuannya. Keberhasilan tujuan pendidikan akan tercapai bila pendidik terlebih dahulu mengetahui watak manusia, sehingga pendidik akan dapat mengatur strategi bagaimana membina manusia dengan latar belakang watak yang beda-beda. Watak itu sendiri menurutnya adalah kondisi bagi jiwa yang mendorong untuk melahirkan tingkah laku tanpa pikir dan pertimbangan atau tingkah laku spontanitas. ${ }^{23}$

Mengenai susunan yang mau diajarkan kepada perserta didik, ibnu miskawaih memandang bahwa pendidikan akhlak harus ditanamkan mulai dari anak usia dini karena perkembangan mental anak masih berevolusi sehingga berkembang sampai menuju kesempurnaan untuk menyimpan pesan-pesan yang sangat baik dan merasuk kedalam jiwa berpikir. $^{24}$

Oleh karenanya pendidikan bukan semata-mata untuk mempelajari ilmu pengetahuan tetapi lebih jauh untuk mengkaji secara mendalam tentang seberapa pengaruh antara ilmu pengetahuan terhadap etika dan akhlak masyarakat, pertama adalah kita harus mengenalkan bagaimana kewajiban-kewajiban syariat kepada peserta didik agar mereka terbiasa melaksanakannya, kedua materi yang berhubungan dengan akhlak perlu diberi contoh agar akhlak terpuji yang di tertanamkan

\footnotetext{
${ }^{21}$ Hasyimiyah Nasution, Filsafat Islam..., hlm. 70.

22 Ibid.

23 Siti, Chodijah. "PENDIDIKAN MENURUT FILSAFAT PENDIDIKAN

ISLAM." Cendekia 9, no. 2 (Juli_desember 2011): 243-264.

${ }^{24}$ Ahmad Syar'i, Filsafat Pendidikan Islam.....hlm. 94.
} 
kepada anak bisa tercapai dengan baik, ketiga yaitu meningkatkan setahap demi setahap pada materi ilmu yang lain sehingga peserta didik mencapai tingkat kemampuan yang sempurna. ${ }^{25}$ (Hasan 2009)

Watak manusia terbagi menjadi dua: Pertama, alamiah dan bertolak dari watak yang berhubungan dengan temprament, misalnya ada orang yang gampang marah karena hal yang sepele, takut menghadapi suatu kejadian tertentu, cemas, dan sebagainya. Kedua, tercipta melalui kebiasaan dan latihan yang pada mulanya keadaan ini terjadi karena dipertimbangkan dan dipikirkan, namun kemudian melalui praktik yang terus-menerus kemudian menjadi karakter. ${ }^{26}$

Dari pembagian Ibnu Miskawaih mengungkapkan bahwa watak manusia tidak alami dalam artian dapat dipengaruhi dan berubah melalui proses pendidikan dan pengajaran. Hal ini senada yang diungkapkan oleh Aristoteles dalam buku Book on Ethics dan Book on Categories yang dikutip Fatah Syukur bahwa orang yang buruk bisa berubah menjadi baik melalui pendidikan, namun belum pasti. Beliau beranggapan bahwa nasehat yang berulang-berulang dan disiplin serta bimbingan yang baik bisa melahirkan hasil-hasil yang berbeda pada berbagai orang, sebagian ada yang tanggap dan segera menerimanya, sebagian juga tanggap tapi tidak segera menerimanya. ${ }^{27}$

Manusia mempunyai perbedaan dalam menerima pendidikan. Ada juga yang kasar, ada yang pemalu, pemarah, dengki, kikir, lemah lembut, ada yang cepat tanggap, ada yang tidak tanggap dan lain semacamnya. Perbedaan-perbedaan (tabiat) ini kalau diabaikan maka dia akan berkembang secara alamiah sesuai dengan tabiat yang dimilikinya. Maka dari itu beliau memandang pentingnya suatu pendidikan (syariat agama) untuk meluruskan agar terbiasa melakukan kebaikan. Karena pendidikan mempunyai tujuan dan fungsi yaitu: kesatu memanusiakan manusia atau menundukkan manusia sesuai dengan substansinya sebagai makhluk yang termulia dari makhluk lain. ${ }^{28}$ Pendidikan di sini berarti

${ }^{25}$ Hasan Basri, Filsafat Pendidikan Islam. (Bandung: Pustaka Setia, 2009), hlm. 231.

${ }^{26}$ Ibnu Miskawaiah, Meniju Kesempurnaan Akblak...,hlm 56.

27 Ramli. "Pendidikan dan Ilmu Pengetahuan Dalam Upaya mencari

Format pendidiakn yang Islami (Kajian Pemikiran Ibnu Miskawaih)." El Furqornia, 01, No. 01 (Agustus 2015): 172-183.

28 Ramli. "Pendidikan dan Ilmu Pengetahuan Dalam Upaya mencari Format pendidiakn yang Islami (Kajian Pemikiran Ibnu Miskawaih)." El Furqornia, 01, No. 01 (Agustus 2015): 172-183. 
berfungsi untuk mengangkat derajat manusia, sebab dari pengetahuan yang didapat melalui daya natiqah yang dimiliki dengan sendirinya akan meninggikan derajat manusianya. Hal ini seperti yang tertulis dalam firman Allah:

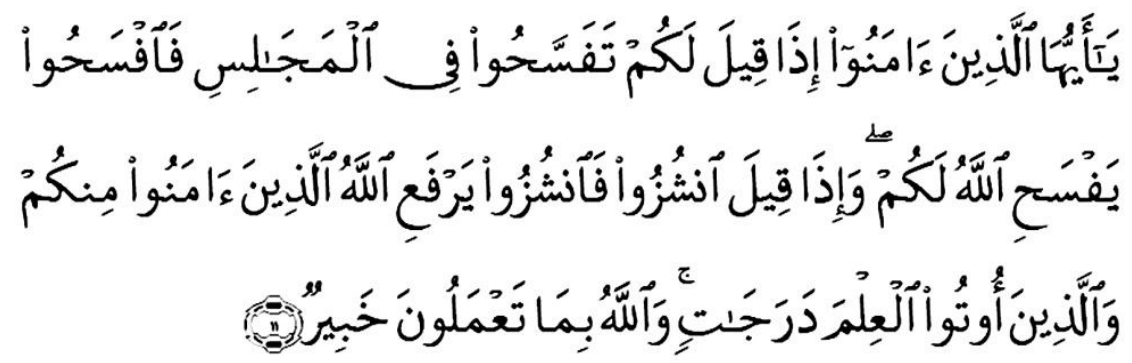

Artinya: "Hai orang-orang beriman apabila kamu dikatakan kepadamu: "Berlapanglapanglah dalam majlis", Maka lapangkanlah niscaya Allah akan memberi kelapangan untukmu. dan apabila dikatakan: "Berdirilah kamu", Maka berdirilah, niscaya Allah akan meninggikan orang-orang yang beriman di antaramu dan orang-orang yang diberi ilmu pengetabuan beberapa derajat. dan Allah Maha mengetahui apa yang kamu kerjakan".

Kedua sosialisasi individu manusia dapat diartikan bahwa pendidikan haruslah mempunyai proses sosialisasi untuk berinteraksi dengan masyarakat karena kebaikan adalah untuk kemaslahatan orang banyak, Sebab pada dasarnya masyarakat merupakan kumpulan dari individu dan apa pun yang ada dalam lingkungan masyarakat, itulah yang akan mewarnai profil individu, yang akhirnya juga akan mewarnai profil peradaban umat manusia. Apabila profil kehidupan setiap individu dalam suatu masyarakat itu baik, dapat diharapkan profil masyarakat itu juga baik. Oleh karena itu perlu adanya sejumlah besar individu dan sekaligus bersatu untuk mencapai kebahagian-kebahagian bersama, sehingga masing-masing dapat kesempurnaannya, dengan cara tolong-menolong, nasehat-menasehati antara satu dengan yang lain. Fungsi yang ketiga menanamkan rasa malu. Penanaman rasa malu terhadap anak merupakan hal yang paling utama sejak anak mengalami tamyiz yakni di mana anak sudah mengetahui dan sudah mulai berfikir kritis. Di sinilah peran orang tua sebagai al-madrasah al-ula untuk mengajarkan dan menanamkan rasa malu, karena dengan menanamkan rasa malu anak terjaga dan terhindar dari berbuat keburukan. Rasa malu (al Haya'u) adalah rasa takut lahirnya 
sesuatu yang buruk dari dirinya. Sehingga sangat penting untuk menanamkan rasa malu karena dalam Islam malu itu sebagian dari pada iman. ${ }^{29}$

Dari ketiga fungsi dan tujuan pendidikan yang digagas oleh Ibnu Miskawaih kalau kita kaitkan dengan pendidikan sekarang ada sisi positif sebagai kontribusi pemikiran untuk mencari format pendidikan yang semakin Islami. Begitu juga ada diantaranya yang perlu kita pertimbangkan mengingat perputaran waktu dan kondisi yang berbeda.

Adapun sisi yang perlu dikembangkan dari gagasan Ibnu Miskawaih walau bagaimanapun juga pendidikan hendaknya tidak mengenyampingkan pendidikan moral. Kalau kita mencoba bercermin dari krisis ekonomi yang baru ini melanda bangsa kita sebetulnya diawali oleh krisis moral, di mana penyelenggaraan pendidikan hanya beroreintasi pada persaingan ekonomi global, sementara garapan moral sebagai pengejawantahan agama kurang mendapat perhatian seakan-akan hanya sebatas pengajaran materi sebagai pelengkap bukan penanaman pendidikan moral yang mengarah kepada kedewasaan dan tanggung jawab, atau dengan kata lain pendidikan hanya menunjukkan "learning for knowledge" tidak "learning to be person".

Sebagai akibat siklus arah pendidikan yang mengenyampingkan fungsi moral manusia telah terkooptasi pada sebuah kontek yang ada untuk menjadikan posisi dan kedudukannya hanya seharga dengan sebuah barang (materi), secara makro kosmos otak manusia modern telah terkontaminasi pada imbas modern secara global sehingga lajur dan kontruksi pemikirannya hanya saja mementingkan jiwa yang lemah yaitu kesenangan dunia.

Ada beberapa hal yang perlu di pertimbangkan berhubungan dengan dunia pendidikan, adapun ungkapan Ibnu Miskawaih masih menekankan pada sisi keilmuan secara normatif, ritualistik dan eskatatologis. Suatu dilema dalam pendidikan selama ini karena masih sangat kurang pendidikan moralnya sehingga masih banyak perbaikan di

${ }^{29}$ Djohar, Profil Religiositas Sosial dalam Pendidikan Islam, dalam Rekonstruksi Pendidikan dan Tradisi Pesantren (Religiusitas Iptek), (Fak.Tarbiyah IAIN Sunan Kalijaga \& Pustaka Pelajar, 1998), hlm. 27.

30 Ramli. "Pendidikan dan Ilmu Pengetahuan Dalam Upaya mencari Format pendidiakn yang Islami (Kajian Pemikiran Ibnu Miskawaih)." El Furqornia, 01, No. 01 (Agustus 2015): 172-183. 
semua lini pendidikan, namun di sisi lain perlu adanya integrasi dan kedinamisan anatara pendidikan moral dengan ilmu pengetahuan agar bisa menyesuaikan dengan kemajuan zaman. Salah satu solusinya pendidikan terkhusus pada pendidikan Islam harus dapat mengembangkan etika dan moral keagamaan yang mempunyai relevansi terhadap perkembangan zaman dengan adanya kemajuan ilmu pengetahuan dan teknologi agar selaras dengan tujuan dan harapan pendidikan Islam bisa berjalan dengan baik dan lancar. ${ }^{31}$

3. Metode

a. Metode Alami (Tabi'iy)

Ibnu Maskawaih mengungkapkan bahwa ide pokok dari metode alami ini merupakan bagaimana pelaksanaan kerja dan proses mendidik itu berdasarkan atas pertumbuhan dan perkembangan manusia secara lahir batin, jasmaniah dan rohaniah.

b. Nasihat dan Tuntunan

Ibnu Maskawaih menyampaikan agar anak mematuhi syariat dan berbudi luhur maka sangat dibutuhkan nasihat dan tuntunan.

c. Metode Hukuman

Ibnu Maskawaih mengindikasikan berbagai permasalahan yang terjadi untuk menjadikan pelajaran dalam mendidik peserta didik, misalnya jika peserta didik tidak melaksanakan tata nilai yang telah diajarkan, mereka diberi sanksi berbagai macam cara sehingga mereka dikembalikan kepada tatanan nilai yang ada.

d. Sanjungan dan Pujian Sebagai Metode Pendidikan

Menurut Ibnu Miskawaih apabila peserta didik melaksanakan syariat dan berbudi luhur maka perserta didik perlu dipuji.

e. Mendidik Berdasarkan Asas-asas Pendidikan

Menurutnya mendidik perlu adanya pondasi yang kokoh seperti asasasas pendidikan yaitu asas kesiapan, keteladanan, kebiasaan dan pembiasaan. $^{32}$

31 Nisrokha. "Konsep Kurikulum Pendidikan Islam (Studi Komperatif Pemikiran AL-Ghozali dan Ibnu Miskawaih)." Madaniyah, 1, no. XII (Januari 2017): 154-173.

${ }^{32}$ Ahmad Syar'i, Filsafat Pendidikan Islam..., hlm. 96. 
4. Pendidik dan Peserta

Pendidik dalam hal ini seorang guru, instruktur, ustadz, atau dosen memegang peran yang sangat penting dalam keberlangsungan kegiatan pengajaran dan pendidikan untuk mencapai tujuan yang telah ditetapkan. Sedangkan anak didik yang biasanya disebut murid, siswa, peserta didik atau mahasiswa merupakan sasaran kegiatan yang sangat penting dalam pengajaran dan pendidikan itu merupakan bagian yang perlu mendapatkan perhatian yang secara maksimal. Perbedaan kemampuan anak didik itu menyebabkan terjadinya perbedaan dalam pemberian materi, metode pendekatan dan sebagainya agar tersalurkan dengan baik.

Sebagai pendidik langkah indahnya bisa menyatukan diri dengan peserta didiknya (baik secara emosional, spiritual atau secara intelektual), lingkunganya dan materi pelajaranya sehingga pendidik benar-benar memahami keadaan materinya secara menyeluruh baik tekstual atau konstektual, sekaligus memahami peserta didiknya secara menyeluruh. Hal ini senada dengan cara Ibnu Arabi untuk mencapai wabdatul wujud atau menyatunya diri dengan Tuhan.33

Kedua aspek pendidikan (pendidik dan anak didik) ini mendapat perhatian yang khusus dari Ibn Miskawaih. Menurut beliau orang tua merupakan pendidik yang mula-mula bagi anak-anaknya dengan bekal syariat sebagai acuan utama materi pendidiknya. Karena peran yang segitu besar dari orang tua dalam kegiatan pendidikan, maka perlu adanya hubungan yang harmonis antara orang tua dan anak yang disandarkan pada kasih sayang. Namun cinta seseorang terhadap gurunya menurut Ibnu Miskawaih harus melebihi cintanya terhadap orang tuanya sendiri.

Pribadi guru memiliki andil yang sangat besar terhadap keberhasilan pendidikan, khususnya dalam kegiatan pembelajaran. Pribadi guru juga sangat berperan dalam membentuk pribadi peserta didik. Ini dapat dimaklumi karena manusia merupakan mahkluk yang suka mencontoh, termasuk mencontoh pribadi gurunya dalam

33 Muhammad Anas Ma`arif, 'Tasawuf Falsafi Dan Implikasinya Dalam Pendidikan Islam', Vicratina: Jurnal Pendidikan Islam 3, no. 1 (13 September 2018): 12, http://riset.unisma.ac.id/index.php/fai/article/view/1026. 
membentuk pribadinya. Semua itu menunjukkan bahwa kompetensi personal atau kepribadian guru sangat dibutuhkan oleh peserta didik dalam proses pembentukan pribadinya. Oleh karena itu wajar, ketika orang tua mendaftarkan anaknya ke suatu sekolah akan mencari tahu siapa guru-guru yang akan membimbing anaknya. ${ }^{34}$

Ibnu Miskawaih mendefenisikan bahwa cinta itu banyak jenis, sebab dan kualitasnya. Secara umum beliau membagi cinta terhadap empat bagian. Pertama cinta yang cepat nempel tetapi juga cepat ilang. Kedua, cinta yang cepat nempel tetapi tidak cepat ilang. Ketiga, cinta yang nempelnya lambat tetapi ilangnya cepat pula, dan keempat cinta yang nempel dan ilangnya lambat. Cinta yang didasari pada kenikmatan termasuk cinta yang cepat nempel dan cepat pula ilangnya. Sedangkan cinta yang pada dasarnya karena kebaikan, termasuk cinta yang cepat nempel tetapi lambat ilangnya. Selanjutnya cinta yang didasarkan atas kemanfaatan termasuk cinta yang lambat nempelnya dan cepat pula ilang. Sedangkan cinta yang di dasari oleh semua jenis kebaikan tersebut maka nempel dan ilangnya lambat.

Adapun menurut ibnu miskawaih guru bukan hanya sekedar formal karena jabatan. Tetapi seorang guru harus biasa memiliki berbagai persyaratan diantaranya yaitu bisa dipercaya, pandai, dicintai, biodata hidupnya jelas tidak tercemar di dalam masyarakat maupun negara. Disamping itu seorang guru hendaknya menjadi cerminan atau panutan dan bahkan harus lebih mulia budi luhurnya dari orang yang dididiknya. ${ }^{35}$

\section{Relevansi Pemikiran Ibnu Miskawaih Tentang Pendidikan di Era Modren}

Miskawaih mendefenisikan bahwa pendidikan yang sistematis dapat dilaksanakan apabila didasari dengan pengetahuan mengenai jiwa yang benar. Oleh karena itu pengetahuan mengenai jiwa yaitu sangat penting sekali dalam proses pendidikan. Kajiannya mengenai konsep pendidikan yang dikemukakan oleh Ibnu Miskawaih diharapkan mampu mengaktualkan

34 Syarnubi. "GURU YANG BERMORAL DALAM KONTEKS SOSIAL, BUDAYA, EKONOMI, HUKUM DAN AGAMA (Kajian Terhadap UU NO 14 Tahun 2005 Tentang Guru dan Dosen)." Jurnal PAI Raden Fatab 1, no. 1 (Januari 2019): 21-40.

35 Sirajuddin Zar, Filsafat Isalam: Filosof dan Filsafatnya, (Jakarta: PT RajaGrafindo Persada, 2012). hlm. 129-134. 
konsep pendidikan Islam dalam skala khusus maupun umum terutama pendidikan akhlak sangat penting untuk ditanamkan secara komprehensif karena di setiap adat istiadat mempunyai beberapa norma etika atau tata susila yang harus dipatuhi. Oleh karena itu moral adalah suatu fenomena manusiawi yang bersifat universal, komprehensif dan aktual yang hanya terdapat pada diri manusia. ${ }^{36}$

Dilihat dari karya Ibnu Miskawaih belum di temukannya buku yang berjudul pendidikan secara langsung. Hanya ada beberapa buku yang tulisanya mengacu kepada pendidikan dan kejiwaan, akal serta etika. Diantara sebayak buku yang diterbitkan ada satu buku yang dinilai memiliki arti tantang konsep pendidikan yaitu kitab Tahrib al-Akblak wa Tathbir al-A'raq telah banyak diterjemahkan berbagai bahasa dan menjadi rujukan berbagai para ulama dalam dunia pendidikan.

Ibnu Miskawaih mengungkapkan bahwa Konsep pendidikan tersebut merujuk kepada tiga bagian yaitu merujuk pada kondisi psikologis, kognitif dan kesiapan peserta didik yang dijabarkan kedalam tiga tingkatan yaitu bayani untuk kemampuan tingkat awal, burhani untuk kemampuan tingkat menengah dan 'irfani untuk kemampuan tingkat tinggi bisa dilihat dari kematangan cara berintelektual. Oleh karena itu dari berbagai segi materi dan tujuanya maka dikelompokkan menjadi tiga bagian yaitu empirik bagi pemula, logik bagi menengah dan etik bagi tinggi.

Penerapan sistem koedukasi dalam dunia pendidikan Islam menurut Al-Qabisy bahwa kurang baik antara anak laki-laki dan perempuan bersatu didalam suatu kelas, karena bisa dikhawatirkan akan rusak moralnya, maka dikotomi tempat pendidikan wajib dilakukan agar terjaga keselamatan anakanak dari penyimpangan norma-norma agama. Rasyid Ridha menolak terdapat adanya manfaat dari pemebelajaran koedukasi dan ia juga beranggapan bahwa koedukasi tidak hanya banyak kekurangan, tetapi juga bisa mendatangkan malabahaya terutamanya kepada kaum wanita.

Al-Qabisy mengurai kurikulum pendidikan Islam kedalam dua bagian yaitu ilmu asasi/wajib (ijbari) dan ilmu yang bukan asasi/tidak wajib (ikbtiyariy). Aspek pertama menguraikan berbagai materi Al-Qur'an dan Hadits yang akan diajarkan dan diterapkan secara asasi kepada ruang lingkup lembaga pendidikan tersebut. Sementara itu aspek kedua yakni aspek

\footnotetext{
${ }^{36}$ Safii. "Ibn Miskawaih (Filsafat al-Nafts dan al-Akhlaq." Teologia 25, no. 1 (Januari-Juni 2014): 1-13.
} 
mu'amalah, diserahkan kepada komponen pelaksana dan penanggung jawab pendidikan yang dapat dikondisionalkan. ${ }^{37}$

Ibnu Miskawaih dalam pemikirannya tentang etika, ia memulainya dengan menyelami jiwa manusia. Ia memandang bahwa ilmu jiwa memiliki keutamaan sendiri dibandingkan dengan ilmu-ilmu jiwa lainnya. Etika menurut Ibnu Miskawaih adalah keadaan jiwa yang melakukan perbuatan tanpa pikiran dan perenungan. Adapun sikap mental terbagi dua dimensi yaitu satu berasal dari watak dan yang satu berasal dari kebiasaan secara terusmenerus. Ajaran etika Miskawaih berpangkal pada teori jalan tengah yang intinya menyebutkan bahwa keutamaan akhlak secara epistemologi dapat diartikan sebagai posisi tengah antara kelebihan dari dalam diri manuisa maupun kekurangan dari dalam jiwa manusia. Dengan demikian menurut Ibnu Miskawaih akhlak merupakan perikeadaan jiwa yang menganjurkan sesorang untuk melakukan perbuatan tanpa dipikirkan dan diperhitungkan sebelumnya agar dapat dijadikan sebagai fitrah manusia maupun hasil dari latihan-latihan yang dilakukan secara terus-menerus hingga menjadi sifat dalam diri yang melahirkan akhlak mahmudah.

\section{KESIMPULAN}

Ibnu Maskawaih mengungkapkan ada saatnya manusia mengalami perubahan hati sehingga membutuhkan aturan-aturan syariat, nasihat dan ajaran adat istiadat terkait sopan santun. Bahkan ia melihat betapa pentingnya proses pendidikan akhlaq kepada anak. Menurut pendapatnya jiwa seorang anak itu seperti putaran mata rantai mulai dari jiwa kebinatangan maupun jiwa manusia yang berakal sehat. Sementara itu nilai-nilai budi luhur yang baik maka akan menumbuhkan keutamaan yang sangat diperlukan seperti aspek jasmani maupun rohani. Beliau mewajibkan bagaimana tata pergaulan anakanak terhadap sesamanya dan perlu adanya proses penanaman yang intensif dan secara rutin agar terciptanya sifat kejujuran, qonaah, pemurah, suka mengalah, mengutamakan kepentingan orang lain, taat, menghormati kedua orang tua, serta selalu berpikir secara positif dan berusaha konsisten dalam hal kebaikan.

Ibnu Maskawaih telah menguraikan sifat manusia kedalam tiga tingkatan yaitu sifat kebinatangan, sifat binatang buas dan sifat yang cerdas.

\footnotetext{
${ }^{37}$ M.M. Syarif, Terjemah Buku Tiga, Bagian Tiga, "The Philosophers", dari Buku History of Muslim Philosophy, (Bandung : MIZAN, 1985). hlm. 120-121.
} 
Hal ini beliau jelaskan menggunakan ungkapan bahwa setiap manusia memiliki potensi untuk bebuat baik begitu pula manusia yang memiliki potensi untuk berbuat buruk. Ibnu Maskawaih melihat segitu pentingnya arti pendidikan dan lingkungan bagi seorang manusia dalam koneksinya dengan pembinaan akhlak. Oleh sebab itu manusia memakai akal sehatnya untuk memilih dan membedakan mana prilaku yang seharusnya dilakukan dan mana prilaku yang harus ditinggalkan.

Pemikiran Ibnu Maskawaih dalam pendidikan bertumpu pada konsep tentang manusia dan pendidikan akhlak. Ibnu Maskawaih memandang manusia sebagai makhluk yang memiliki tiga daya, dari tiga macam daya tersebut yaitu terdiri dua terdapat pada unsur materi dan yang satu lagi terdapat pada ruh Tuhan. 


\section{DAFTAR PUSTAKA}

Ahmad, Amin. Dhubr al-Islam, Jus II. Beirut: Dar Al-Kitab Al Araby, 1969.

Ahmad, Syar'i. Filsafat Pendidikan Islam. Jakarta: Pustaka Frdaus, 2005.

Dedi , Supriyadi. Pengantar Filsafat Islam: Konsep, Filusuf dan Ajarannya. Bandung: Pustaka Setia, 2009.

Djhor. Profil Religiositas Sosial dalam Pendidikan Islam, dalam Rekonstruksi Pendidikan dan Tradisi Pesantren (Religiusitas Iptek). Yogyakarta: Fak. Tarbiyah dan Keguruan IAIN Sunan Kalijaga \& Pustaka Belajar, 1998.

Hasan, Basri. Filsafat Pendidikan Islam. Bandung: Pustaka Setia, 2009.

Hasyimiyah, Nasution. Filsafat Islam. Jakarta: Gajah Mada Press, 1999.

Ibnu , Miskawaih. Tahzib al-Akhlaq wa al-Takhthir al-A'raq. Mesir: alHusainiyah, $1392 \mathrm{H}$.

Istighfarotul , Rohmaniyah. Pendidikan Etika: Konsep Jiwa dan Etika Perspektif Ibnu Miskawaih dalam Kontribusinya di Bidang Pendidikan. Malang: UIN Malang Press, 2010.

M.M, Syarif. Para Filosof Muslim. Bandung: Mizan, 1998.

Mustofa. Filsafat Islam. Bandung: Pustaka Setia, 2007.

Ma`arif, Muhammad Anas. 'Tasawuf Falsafi Dan Implikasinya Dalam Pendidikan Islam'. Vicratina: Jurnal Pendidikan Islam 3, no. 1 (13 September 2018). http://riset.unisma.ac.id/index.php/fai/article/view/1026.

Nisrokha. "Konsep Kurikulum Pendidikan Islam (Studi Komperatif Pemikiran AL-Ghozali dan Ibnu Miskawaih)." Madaniyah 1, no. XII (Januari 2017): 154-173. 
Nizar. "Pemikiran Etika Ibnu Miskawaih." AQLAM Journal of Islam and Plurality 1, no. 1 (Juni 2016): 35-42.

Ramli. "Pendidikan dan Ilmu Pengetahuan Dalam Upaya mencari Format pendidiakn yang Islami (Kajian Pemikiran Ibnu Miskawaih)." El Furqornia 01, no. 01 (Agustus 2015): 172-183.

Rosif. "Dialektika Pendidikan Etika dalam Islam (Analisis Pemikirn Ibnu Miskawaih)." Pendidikan Agama Islam 3, no. 2 (November 2015): 394417.

Rosnita. "PEMBENTUKAN AKHLAK ANAK USIA DINI Menurut IBNU MISKAWAIH." MIQOT XXXVII, no. 2 (juli-desember 2013): 396-414.

Safii. "Ibn Miskawaih (Filsafat al-Nafts dan al-Akhlaq." Teologia 25, no. 1 (Januari-Juni 2014): 1-13.

Sirajuddin, Zar. Filsafat Islam: Filosof dan Filsafatnya. Jakarta: PT Raja Grafindo Persada, 2012.

Siti, Chodijah. "PENDIDIKAN MENURUT FILSAFAT PENDIDIKAN ISLAM." Cendekia 9, no. 2 (Juli_desember 2011): 243-264.

Syarnubi. "GURU YANG BERMORAL DALAM KONTEKS SOSIAL,BUDAYA, EKONOMI, HUKUM DAN AGAMA (Kajian Terhadap UU NO 14 Tahun 2005 Tentang Guru dan Dosen)." Jurnal PAI Raden Fatah 1, no. 1 (Januari 2019): 21-40.

Tim Pengembang Ilmu Pendidikan. Ilmu dan Aplikasi Pendidikan. Jakarta: Imperial Bhakti Utama, 2007. 